EESTI NSV TEADUSTE AKADEEMIA TOIMETISED 1955. IV kd., nr. 4 ИЗВЕСТИЯ АКАДЕМИИ НАУК ЭСТОНСКОИ ССР 1955. Том IV, N 4

\title{
К ВОПРОСУ Оे РОЛИ ЛЕЙКОЦИТОВ В ПРОЯВЛЕНИИ АЛЛЕРГИЧЕСКОГО СОСТОЯНИЯ ОРГАНИЗМА К ТУБЕРКУЛЕЗНОМУ АНТИГЕНУ
}

\section{В. А. ФРАДКИН}

Прошло более 50 лет с тех пор, как было создано учение об аллергии. Проблема реактивности организма, являясь отправным пунктом этого учения, обусловила его прогрессивную роль в изучении патогенеза различных заболеваний.

Вопросы аллергии занимают видное место в иммунологии, биохимии и патологической физиологии. Не меньшую роль они играют и в клинической медицине. Учение об аллергии, как указывал Н. Д. Стражеско $\left({ }^{13}\right)$, позволило клиницисту правильно оценить течение и симптоматологию инфекционных процессов, облегчило понимание их патогенеза и направило профилактику и терапию инфекционных заболеваний на правильный путь.

Особое значение аллергия имеет при туберкулезе. Динамика развития этой инфекции тесно связана с уровнем сенсибилизации заболевшего организма по отношению к специфическим микробным антигенам. Еще исследованиями Р. Коха $\left({ }^{16}\right)$ и И. И. Мечникова $\left({ }^{9}\right)$ было показано, что реакция подопытных животных на повторное введение возбудителя туберкулеза претерпевает значительные изменения по сравнению с начальной реакцией организма. Однако до сегодняшнего дня эти изменения изучены недостаточно. Причину этого следует искать прежде всего в отсутствии единого мнения в оценке аллергии и ее значения при туберкулезе. В то время как одни $(2,4)$ разделяют аллергию и иммунитет на два независимых друг от друга процесса, другие $\left({ }^{2,5}\right)$ признают их единство.

Нет общности взглядов и по вопросу желательности или нежелательности аллергии при туберкулезе. Заслуживает внимания мнение В. Ф. Чернышева $\left({ }^{14}\right)$ о том, что с аллергией не следует «бороться», а необходимо выявить такие условия, при которых она, пройдя через ряд фаз, могла бы быстро привести к повышению сопротивляемости организма.

Оценка аллергического состояния организма к туберкулезному антигену с момента создания учения об аллергии чаще всего производилась посредетвом накожных туберкулиновых реакций, которые теперь в ряде случаев дополняются определением высоты туберкулинового титра $\left({ }^{8}\right)$.

Параллельно с этим развивалось и другое направление, представители которого для этой цели изучали реакции тканевых элементов организма. Прочным фундаментом для подобного рода исследований явились наблюдения И. И. Мечникова $\left({ }^{7}\right)$, установившего активную фагоцитарную реак- 
цию лейкоцитов в отношении туб́еркулезной культуры, введенной в кровяное русло. В дальнейшем рядом работ было показано диагностическое значение исследования белой крови при определении аллергии $\left({ }^{6,12}\right)$ и установлена фагоцитарная активность элементов крови при различных аллергических состояниях $\left({ }^{10}\right)$. Таким образом, совершенно очевидно, что лейкоциты крови принимают непосредственное участие в формировании иммунологических и аллергических реакций при туберкулезе. В свете этого уместно подчеркнуть, что влияние перелитой крови на динамику туберкулезного процесса до сих пор обычно рассматривалось в основном лишь с локалистических позиций - изменений в местном туберкулезном очаге, который, хотя и является проявлением общего заболевания организма, однако не определяет всех иммунологических и аллергических сдвигов в последнем.

В настоящее время уже опубликован ряд работ, затрагивающих проблему изменения реактивности животного организма к туберкулину под воздействием перелитой крови и ее составных частей.

Так, Цинсер и Мюллер $\left({ }^{18}\right)$, вводя сыворотку крови туберкулезных кроликов здоровым морским свинкам, получали у последних положительную реакцию на туберкулин. Другим подтвердить эти данные не удалось.

P. Я. Поляк $\left({ }^{11}\right)$, изучая возможность пассивного переноса аллергии при переливании крови, получил в основной массе своих опытов отрицательные результаты.

Наоборот, Чейз $\left({ }^{15}\right)$ и др., вводя нормальным морским свинкам отмытые клетки брюшного экссудата, полученные от сенсибилизированного животного, а также взвесь из клеток селезенки и лимфатических узлов, регистрировал положительные туберкулиновые пробы в течение 5 суток после 2 - 3-дневного латентного периода. Ставицкий $\left({ }^{17}\right)$, кроме того, отметил в двух случаях пассивный перенос аллергии к туберкулезным антигенам при переливании цельной крови.

Такая противоречивость выводов, сделанных различными авторами при попытках решить данную проблему экспериментальным путем, исключает возможность каких-либо конкретных рекомендаций в целях использования их в общем арсенале противотуберкулезных мероприятий.

Широкое распространение в практике советского здравоохранения переливания цельной крови и ее элементов вызывает настоятельную необходимость глубокого и всестороннего изучения аллергических сдвигов в организме реципиента, которые могут возникнуть в результате гемотрансфузий. Такие терапевтические воздействия особенно широко применяются в отношении тех категорий больных, которые, не будучи туберкулезными больными, являются носителями первичного комплекса. Изучая литературу по этому вопросу, нам не удалось обнаружить работ, освещающих динамику аллергии к туберкулину в организме таких реципиентов до и после переливания крови.

А между тем только в глубоком изучении всех факторов внешнего воздействия, способных нарушить относительное равновесие между организмом и внешней средой, заложены условия познания причин обострения туберкулезного процесса, что имеет огромное значение для лечения и профилактики этого заболевания. Сознавая недопустимость распространения пока еще малочисленных экспериментов на естественные процессы в организме человека, а также учитывая противоречивость существующих мнений, мы сочли необходимым экспериментально изучить явление «пассивной» аллергии к туберкулину.

При этом было принято a priori, что реакция на туберкулин в значительной мере отражает чувствительность организма к живому возбудителю туберкулеза. 
Опыты проводились на еветлых морских свинках весом в $350-450$ граммов.

Для исключения из опыта животных с повышенной чувствительностью к туберкулину, всем им на депилированной коже спины ставилась туберкулиновая проба по Манту $(0,1$ мл в разведении $1: 10)$. Такие же пробы ставились и в ходе опытов. Учет реакции во всех случаях производился спустя 24 и 48 часов (окончательная оценка) путем фиксирования ее интенсивности, распространенности, наличия или отсутствия некроза. Активная аллергизация морских свинок-доноров осуществлялась туберкулезными культурами различной вирулентности путем парентерального введения 40 миллионов микобактерий в объеме 0,2 мл. Нами были использованы: 1) Mycobacterium tuberculosis typus humanus (№ 5), штамм, выделенный от больного и проверенный на вирулентность в лаборатории микробиологии Института экспериментальной и клинической медицины Академии наук Эстонской ССР, 2) Mycobacterium tuberculosis typus humanus «Academia», штамм, полученный из Центрального государственного научного контрольного института им. Тарасевича и являющийся слабо вирулентным экспериментальным штаммом.

«Пассивно» аллергизирующим субстратом являлись лейкоциты, добытые из внутрибрюшинного воспалительного очага, созданного стерильным мясо-пептонным бульоном.

Взвесь лейкоцитов из брюшного экссудата получалась следующим образом. Морской свинке внутрибрюшинно вводился стерильный бульон. Спустя 5 часов посредством прокола иглой собнрался самотеком экссудат (до 10 мл). После центрифугирования надосадочный слой сливался, а осадок экссудата отмывался в растворе Рингера-Локка и вводился нормальным морским свинкам. * До центрифугирования экссудат засевался на яично-картофельную среду и из него готовился мазок, который окрашивался по Циль-Нельсену и Романовскому. Исследование клеточного состава экссудата под микроскопом показало, что в $1 \mathrm{mм}^{3}$ содержится $11000-13000$ лейкоцитов, из которых 79-84\% составляют нейтрофилы, 8-11\% - лимфоциты; остальные формы встречались редко.

Учитывая, что при парентеральном заражении нормальных морских свинок туберкулезом кожные туберкулиновые реакции появляются у них после девятого дня, мы относили к «пассивной» аллергии лишь те положительные туберкулиновые пробы, которые были отмечены до этого срока.

Эксперименты были проведены на 102 морских свинках. Из них 10 являлись донорами, 74 - реципиентами, а 18 - контрольными. До начала основных опытов были подвергнуты проверке уже известные из литературы данные о том, что даже частые внутрикожные инъекции туберкулина не могут сами по себе обусловить появление положительных туберкулиновых реакций.

Для этого восьми здоровым морским свинкам неоднократно (до 7 раз), с интервалами в 48 часов, ставились внутрикожные туберкулиновые пробы. Во всех случаях положительные реакции отсутствовали. Вторым предварительным контролем явился опыт, который должен был выявить возможность «пассивного» повышения чувствительности к туберкулину при внутрибрюшинном введении нормальным морским свинкам лейкоцитов, добытых по описанной выше методике от таких же нормальных животных. Ни у одной из 10 морских свинок-реципиентов, участвовавших в этом контроле, повышения чувствительности к туберкулину не наблюдалось (рис. 1, IV).

* Под нормальной морской свинкой мы подразумеваем животное, отрицательно реагирующее на туберкулин и никогда ранее не использовавшееся в каких-либо опытах. 

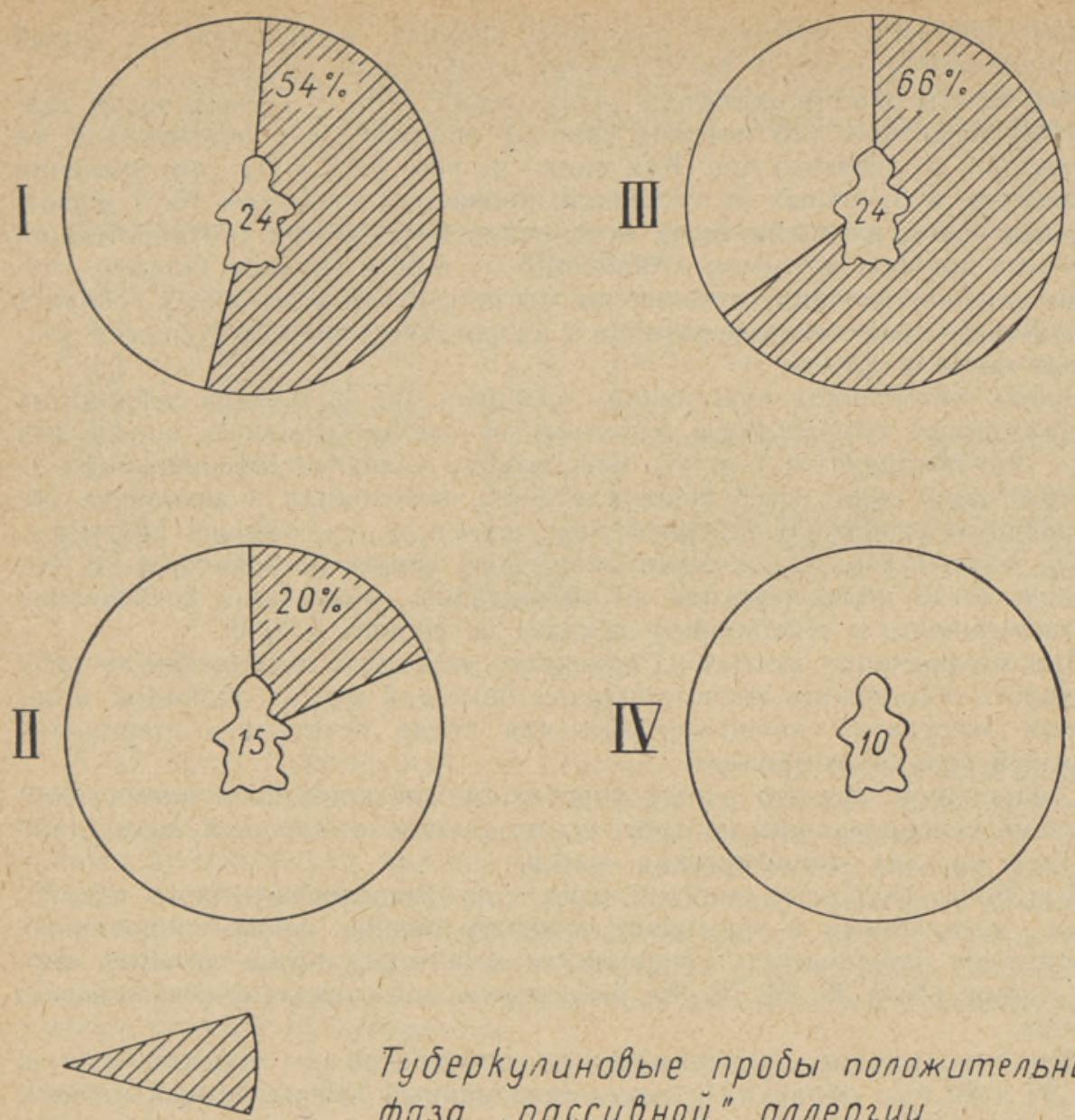

Туберкулиновые пробы попожитепьны фаза "пассивной" аллергии

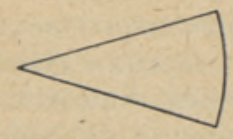

\section{Туберкупиновые пробы отрииательны- "naccubнar" aлnергия omcymcmbyem}

Рис. 1. Возникновение «пассивной» аллергии после введения нормальным морским свинкам лейкоцитов и надосадочной части, экссудата, зараженных туберкулезом животных.

I - Введены лейкоциты животных, зараженных туберкулезной культурой человеческого типа (штамм № 5). II - Введены лейкоциты животных, зараженных туберкулезной культурой человеческого типа (штамм «Akademia»). III - Введена надосадочная жидкость экссудата. Получена от животных, зараженных штаммами № 5 или «Akademia». IV - Введены лейкоциты здоровых животных - контроль. (Цифры внутри каждой фигуры указывают на число животных в опыте.)

Основные опыты были начаты с выяснения возможности получения в организме нормальной морской свинки состояния повышенной чувствительности к туберкулину после введения ей лейкоцитов от животного, зараженного живой туберкулезной культурой. Во всех известных нам работах для активной аллергизации животных-доноров использовалась убитая туберкулезная культура, в то время как, исходя из естественных жиз- 
ненных условий и интересов практики, вариант эксперимента с живой туберкулезной культурой представляет наибольший интерес.

Результаты опытов оказались следующими: $60 \%$ от общего числа подопытұых животных (48 морских свинок) положительно реагировали на туберкулин до девятого дня. Как видно из рис. 1 (I и II), при введении лейкоцитов, полученных от сенсибилизированных штаммом № 5 животных, пассивная аллергия была отмечена в $54 \%$, а при сенсибилизации животных-доноров штаммом «Akademia» - в $66 \%$ случаев. Однако, учитывая среднюю величину отклонения, мы не считаем возможным говорить о какой-либо существенной разнице в аллергизирующей способности указанных выше штаммов.

Продолжительность «пассивной» аллергии при получении лейкоцитов от зараженных туберкулезом животных не всегда удавалось определить точно. Это объясняется тем, что «пассивная» аллергия (возникающая до девятого дня) чаще всего непосредственно переходила в активную, обусловленную развитием туберкулезного процесса, что обычно подтверждалось материалом патологоанатомического вскрытия животных. В тех случаях, когда этого перехода не наблюдалось, возникшая повышенная чувствительность к туберкулину длилась не дольше 5 дней.

При микроскопии взятых из брюшного экссудата лейкоцитов ни разу не удалось обнаружить кислотоупорных бактерий или их обломков, а засеянная экссудатом яично-картофельная среда өставалась стерильной (видимый рост отсутствовал).

Следует отметить, что у ряда морских свинок, длительное время положительно реагировавших на туберкулин, секция не выявила каких-либо заметных на глаз специфических очагов.

Для более глубокого ознакомления с патоморфологическими изменениями, возникшими в организме морских свинок, аллергизированных лейкоцитами зараженных туберкулезом животных, легкие четырех морских свинок (№№, 25, 28, 78, 89) были взяты для гистологического исследования.

При микроскопии приготовленных препаратов у морских свинок №№ 25 и 89 был обнаружен диссеминированный туберкулезный процесс с распадом легочной ткани.

У морской свинки № 78 была обнаружена общая инфильтрация легочной ткани и отдельные нерезко выраженные туберкулезные очаги.

У морской свинки № 28 установлена картина неспецифического воспа: ления, эозинофилия. При этом уместно подчеркнуть, что морская свинка № 28, несмотря на отсутствие специфических туберкулезных поражений, в продолжение шести месяцев, прошедших с момента введения ей лейкоцитов, положительно реагировала на внутрикожные туберкулиновые пробы. Все это позволяет предположить возможность наличия в лейкоцитах настолько ослабленных форм туберкулезных микобактерий, что при гіервом пассаже они вызывают лишь аллергическую перестройку организма, без ясно выраженных структурных изменений внутренних органов.

В ходе работы перед нами возник вопрос о чувствительности морских свинок-реципиентов к повторному введению им лейкоцитов от активно аллергизированных животных. Для выяснения этого вопроса морским св́нкам, утратившим способность положительно реагировать на туберкулин, которая у них обнаруживалась после первичного введения лейкоцитов, повторно вводились клеточные элементы.

Как показывает таблица 1, пять морских свинок из семи не обнаружили аллергии к туберкулину в ответ на повторное введение лейкоцитов, хотя после первого введения элементов все они реагировали на тот же антиген до девятого дня. 
Незначительное число животных, использованных в этом опыте, не позволяет сделать каких-либо обоснованных выводов. Однако факт изменения реактивности организма после первично переданной «пассивной» аллергии сам по себе представляет интерес и заслуживает внимания.

Таблица 1

\section{Возникновение «пассивной» аллергии после первичного и повторного введения} лейкоцитов

\begin{tabular}{|c|c|c|c|c|c|c|c|}
\hline \multirow{4}{*}{ 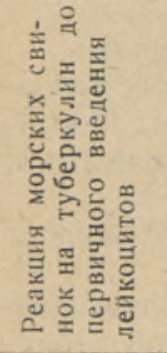 } & \multirow{3}{*}{\multicolumn{2}{|c|}{$\begin{array}{c}\text { Реакция морских } \\
\text { свинок на тубер- } \\
\text { кулин после пер- } \\
\text { вичного введения } \\
\text { лейкоцитов } \\
\text { (до 9-го дня) }\end{array}$}} & \multirow{4}{*}{ 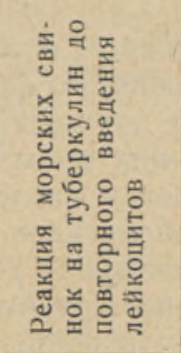 } & \multicolumn{4}{|c|}{$\begin{array}{l}\text { Реакция морских свинок на туберкулин } \\
\text { после повторного введения лейкоцитов } \\
\text { (до 9-го дня) }\end{array}$} \\
\hline & & & & \multicolumn{2}{|c|}{ положительная } & \multicolumn{2}{|c|}{ отрицательная } \\
\hline & & & & & Из них реа- & & Из них реа- \\
\hline & $\begin{array}{l}\text { положи- } \\
\text { тельная }\end{array}$ & $\begin{array}{l}\text { отрица- } \\
\text { тельная }\end{array}$ & & Bcero & $\begin{array}{l}\text { гировало по- } \\
\text { сле первого } \\
\text { введения } \\
\text { лейкоцитов }\end{array}$ & Bcero & $\begin{array}{l}\text { гировало по- } \\
\text { сле первого } \\
\text { введения } \\
\text { лейкоцитов }\end{array}$ \\
\hline отсу & 6 & 1 & отсутствует & 2 & 1 & 5 & 5 \\
\hline
\end{tabular}

А. Д. Адо (') обнаружил, что сывороточные или бактериальные антигены способны возбуждать хеморецепторы сосудистых рефлексогенных зон у взрослых собак или кроликов значительно раньше, чем у них удается воспроизвести положительные кожные аллергические реакции. Исходя из его наблюдений, мы сочли возможным выяснить начальные сроки аллергизации лейкоцитов в кровяном русле морских свинок, которым была введена туберкулезная культура, и сопоставить полученные результаты с динамикой появления у этих же животных положительных кожных реакщий на туберкулин.

С этой целью спустя 2 дня после введения морским свинкам туберкулезной культуры у них из брюшной полости получали экссудат. Осадок экссудата отмывали и вводили нормальным морским свинкам.

У 4 морских свинок из 11 (из числа тех, которым вводились лейкоциты) положительные реакции на туберкулин были отмечены до девятого дня, хотя у животных-доноров кожные туберкулиновые пробы в момент взятия у них экссудата были отрицательными.

Данные нашего эксперимента указывают, что лейкоциты, полученные из брюшного экссудата зараженной туберкулезом морской свинки и введенные в организм здоровой морской свинки, могут вызывать у последней состояние повышенной чувствительности к туберкулину еще до того, как кожа активно аллергизированного животного оказывается способной ответить на введение этого же антигена аллергической реакцией.

Для всестороннего анализа изучаемого явления была уточнена возможность «пассивной» передачи нормальным морским свинкам повышенной чувствительности к туберкулину при внутрибрюшинном введении им надосадочной жидкости, образующейся при центрифугировании экссудата. Объем вводимой жидкости равнялся 8-9 мл. Как видно из рис. 1, III, только $20 \%$ от общего числа животных обнаружили повышенную кожную чувствительность к туберкулину до девятого дня.

Возникновение этих положительных реакций, на наш взгляд, объясняется тем, что при собирании экссудата, его последующем отмывании и центрифугировании некоторая часть лейкоцитов повреждается и их содержимое переходит в надосадочный слой. Известное воздействие здесь 
могла оказать и неспецифическая сенсибилизация, вызванная присутствием в надосадочной жидкости мясного бульона.

Сопоставляя сроки появления пассивной аллергии к туберкулину у морских свинок-реципиентов, нельзя не отметить того факта, что в возникновении этой реакции наибольшее значение имеют индивидуальные особенности животного реципиента.

Так, в ряде случаев лейкоциты одной и той же морской свинки, разделенные на две порции и одновременно введенные разным морским свинкам, у одной из них вызывали появление «пассивной» аллергии к туберкулину, а у другой не вызывали.

Исходя из наших наблюдений можно сделать следующие выводы:

1. Лейкоциты, полученные из брюшного экссудата зараженных туберкулезом морских свинок и введенные здоровым морским свинкам, способствуют возникновению в ряде случаев повышенной чувствительности к туберкулину до девятого дня с момента введения элементов.

2. Возникновение «пассивной» аллергии в значительной мере зависит от индивидуальных особенностей животного реципиента.

3. При сравнении аллергизирующих свойств лейкоцитов, полученных от морских свинок, зараженных вирулентной и слабовирулентной туберкулезными культурами человеческого типа, существенной разницы отметить не удается.

4. Лейкоциты зараженной туберкулезом морской свинки могут вызывать в организме здоровой морской свинки состояние повышенной чувствительности к туберкулину р аньше, чем кожа животного, от которого были получены эти лейкоциты, приобретает способность отвечать аллергической реакцией на тот же антиген. Следовательно, в процессе аллергической перестройки организма при заражении туберкулезом лейкоциты сенсибилизируются к туберкулезному антигену раньше, чем- наружные кожные покровы.

Ннститут экспериментальной и клинической медицины Академии наук Эстонской ССР

Поступила в редакцию 23 II 1955

\section{ЛИТЕРАТУРА}

1. А. Д. Адо, Некоторые возрастные особенности аллергической реактивности организма. Возрастные изменения обмена веществ и реактивности организма. Труды конференции по возрастным изменениям и реактивности организма, Киев, 195I, стр. $74-84$.

2. М. Р. Барок, Аллергия и десенсибилизирующая терапия в клинике легочного туберкулеза. Вопросы аллергии и иммунитета при туберкулезе, Л., 1948.

3. В. М. Бе р м а н и Е. К. С в ище в ская, О соотношениях между инфекционным иммунитетом и аллергией при туберкулезе. Вопросы аллергии и иммунитета при туберкулезе, Л., 1948.

4. Ю. К. В ей сфейле р, Механизм нммунитета и аллергии при туберкулезе, «Проблемы туберкулеза», № 2, стр. 3-15, 1946.

5. В. А. Воробье в, Вегетативная жизнь организма и ее роль в патогенезе туберкулеза, «Проблемы туберкулеза», № 2, стр. 153-158, 1936.

6. Ю. П. Ко р о в н н а, Значение исследования белой крови при туберкулинодиагностике. Бюллетень Института туберкулеза АМН СССР, № 1, 1948.

7. И. И. Мечников, О фагоцитарной роли гигантских клеток при туберкулезе. Академическое собрание сочинений, т. 6, Медгиз, 1950, стр. 113-131.

8. Л. М. Модель и Е. Ф. Сидельникова, Туберкулинодиагностика, изд. 2 , 1947.

9. С. Е. Незлин, И. И. Мечников и его роль в разработке современного учения о туберкулезе, «Проблемы туберкулеза», № $7-8$, стр. $77-82,1941$.

10. Г. Е. Платонов и Е. Н. Морозова, Влияние аллергин на клетояную реакцию при туберкулезе. Вопросы патологической анатомии и клиники лимфатических фаз при туберкулезе. М.-Л., 1937, стр. 217-227. 
11. Р. Я. Поляк, О пассивном переносе кожной туберкулезной аллергии путем переливания крови, «Проблемы туберкулеза», №6, стр. 20-25, 1938.

12. А. Е. Р а бу хин, Культура лейкоцитов крови туберкулезных больных в присутствии ВК, «Проблемы туберкулеза», № 1, стр. 42-47, 1941.

13. Н. Д. С т р а жеско, Место и значение аллергии в клинике. Труды Всесоюзной конференции по вопросам аллергии, Киев, 1938.

14. В. Ф. Ч е рны ше в, О взаимоотношениях повышенной реактивности и устойчивости организма (аллергии и иммунитета) в инфекционном процессе, «Проблемы туберкулеза», № 3, 1952.

15. M. Ch a s e, The Cellular Transfer of Gutaneous Hypersensitivity to Tuberculin. Proc. Soc. Exp. Biol. and Med., Vol. 59, No 2, p. 134-135, 1945.

16. R. Koch, Fortsetzung der Mittheilungen über ein Heilmittel gegen Tuberkulose. Deutsche Med. Wochenschrift Nr 3, S. 101, 1891.

17. A. S t a vits ky, Passive Cellular Transfer of the Tuberculin Type of Hypersensitivity. Proc. Soc. Exper. Biol. and Med., Vol. 67, No 2, p. 225-227, 1948.

18. H. Z insser and J. H. Mueller, On the Nature of Bacterial Allergies. Journal of Exp. Med., Vol. 41, No 1, p. 159, 1925. 